(C) 1982 ISIJ

\title{
プラズマアーク溶解プロセスの現状と将来性
}

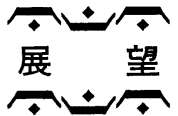

大 澤 秀 雄*.小 野 清 雄*2

\section{The Status and Prospects of Plasma Arc Melting}

\author{
Hideo Osawa and Kiyoo Ono
}

\section{1. 緒}

\section{言}

プラズマに関する研究は，核融合炉実現を日指し，こ こ20 年閒に急激な発展をとげた，核融合炉の笑用化の 道はまだ険しいものがあるが，その研究の発展過程にお いて，プラズー科学技術の多方面への適用が，派生的に

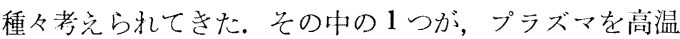
の熱源として利用する陚みである。

通常の放電アークを，強制的に拘束し，いわゆる Thermal pinch 效果によつて得られる，上り高温のアーク， すなわりプラズマアークもしくはプラズマジェットは, ほとんどすべてのガス体を作動ガ入として利用できる特 徵を有している。 それ故に，その高温を利用して化学反 応を促進できることなどの理由により，特に化学工業の 分野に去く利用されており，現在，プラズマ放電現象を 利用した化受晟・分解・蒸着・エッチングなどを総括 するプラズマ化学々いら体系が確立されつつある.

金属の浴断・溶㩲・浴解にプラズマアークの高温特性 を単純に利用しようという考岳は，比較的古くから存在 したと思执れるが，この分野に拈ける工業化は，1950年 代から，まず溶断，漁接の領域で発展した。

金属の溶解の熱源にン゙ラズマアークを利用しようとい ら試みがなされたのは，1960 年代になつてからであり， その工業化の歴史はまだ浅い，金属の溶解の場合は，溶 接に比して大辈力のゾラズマアークを必要とするため, ブラズマアーク発生装等の大型化特に大電流アーク発生 に耐えらるプラズマトーチの開発に問題があつた，世界 各国において, 各種のプラズマアーク溶解プロセスの開 発研究が試みられたが，現在実用化に成功しているの は，ソ連，東独を除けば，白由経済圈では日本にすぎな い.

ソ連，東独に拀いては，量産特殊鋼溶製にも利用され ているが，日本においては，経済的な観点から，高品質 特殊鋼，超合金，高融点金属など高級金属材料の溶解を 対象とする特殊溶解プロセスの熱源として，プラズマア
ークを利用することで開発が進められてきた。しかし最 近，スウェーデン，ベルギー，英国，西独など自由経済 圈諸国においても，製銑，製鋼の大量生産プロセスへの プラズマアークの適用が試みられるなど新しい芽ばえが 起こつている.

本稿では，このよらな現状を含めて，プラズマアーク を熱源とした金属の溶解プロセスの概要と開発の動向並 びに将来性について簡単に述べることにする。なお，プ ラズマアーク溶解精錬造塊プロセスの詳細については, 先に，本誌に技術資料として取りまとめて報告してあ る1). 各国で開発が試みられた各プロセスの発展の経緯 等については，既稿を参考にしていただきたい.

\section{2. プラズマアーク溶解プロセスの現状}

プラズマアークが高温のアークであり，その作動ガス に各種のガス体が利用できることを考光れば，プラズマ アークを金属の溶解精鍊に適用することによつて，次の ような可能性が生ずる，第 1 に，圧力と組成とを制御し た調整雲囲気下における金属の高温溶解が可能となる. 第 2 に，ガス，スラグを利用した金属の溶解精鍊処理が 可能になる，それ故に，高融点を有する金属・合金の溶 解への利用, 真空溶解しがたい蒸気压の高い金属の溶解 あるいは蒸気圧の高い元素を含有する金属・合金の溶解 への利用, 酸素, 窒素, 水素, 炭素などと反応しやすい 金属・合金の溶解への利用などが考えられた。更には, プラズマ放電によつて加熱されたガス体自身による金属 の還元溶解への利用も試みられた。

現在, 実用化されるか実用化が試みられているプラズ マアーク溶解プロ七スを大別すれば次のようになろら.

（1）マグネシアなどの耐火物ライニング溶解容器を 用いる，製鋼用アーク炉プロセス之類似したプラズマア ーク溶解プロセス [Plasma arc melting (=PAM) process].

（2）プラズマアーク加熱と誘導加熱攪拌とを組み合 わせたプラズマ誘導溶解プロセス [Plasma induction 貨利 57 作 3 月 8 日受付 (Received Mar. 8，1982) (依頼展望)

* 大间特殊銅 (株) 工博 (Daido Steel Co., Ltd.)

*2大同特殊鋼 (株) 灲尖研究所工博 (Central Research Laboratory, Daido Steel Co., Ltd., 2-30 Daido-cho Minami-ku Nagoya 457) 


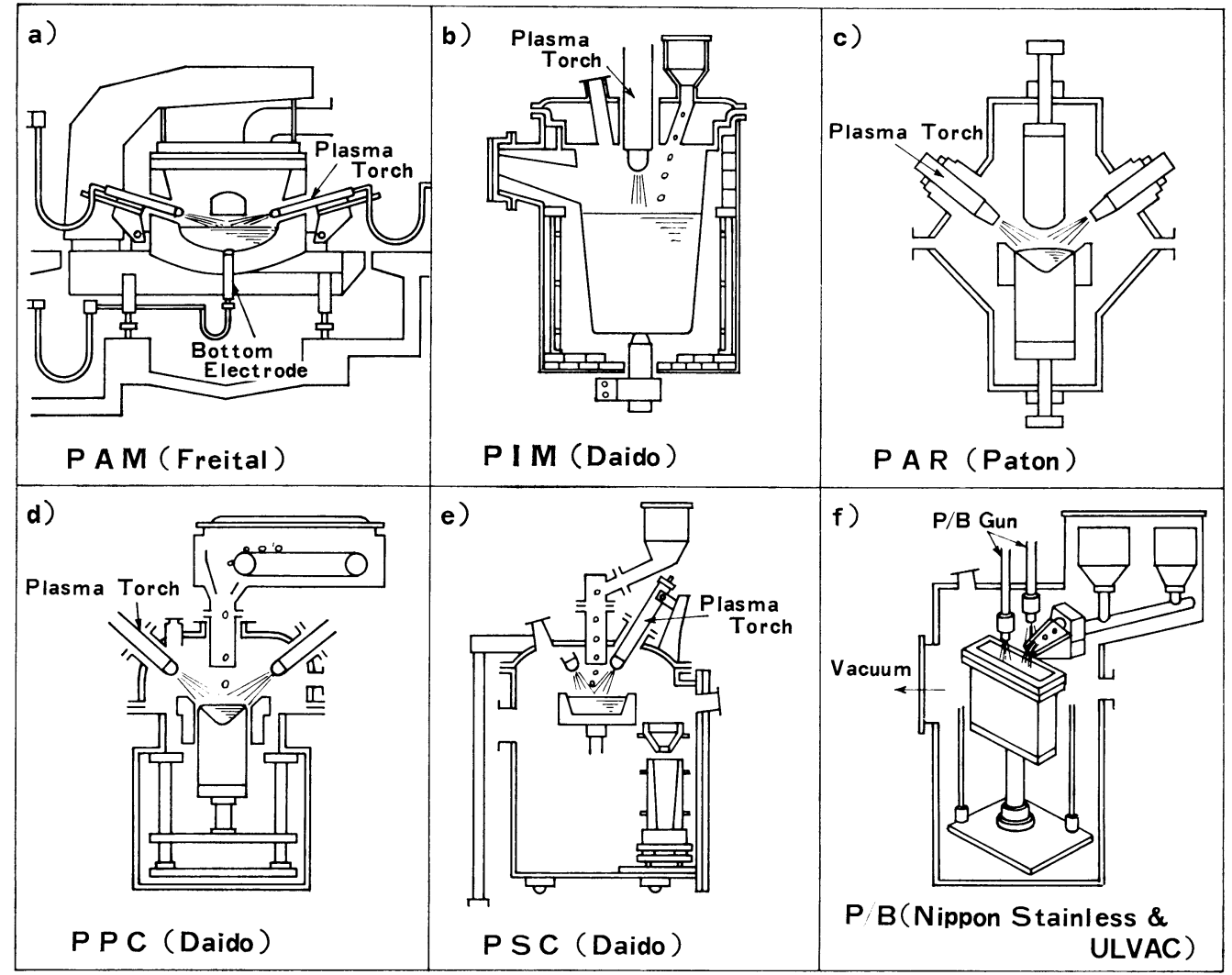

Fig. 1. Schemata of several plasma arc melting processes.

melting (=PIM) process].

（3）水冷モールドによる積層凝固方式のプラズマア ークの再溶解プロセス [Plasma arc remelting (=PAR) process].

（4）水冷溶解谷器を用いる高融点金属, 活性金属な ぞの特殊金属・合金の特殊な溶解精錬鋳造プロセス.

[ex. Plasma progressive casting $(=\mathrm{PPG})$ process -Vacuum plasma electron beam melting $(=\mathrm{P} /$ B) process

- Plasma skull casting (=PSG) process

（5）製銑に関連するプラズマ還元溶解プロセ火 [Plasmasmelting process].

Fig. 1 に形式 $(1) \sim(4)$ のプラズマアーク溶解プロ セスの概略図を示した，以下に個々のプロ七スの現状に ついて略述する。

\section{$2 \cdot 1$ PAM プロセス}

このプロセスは，一般には，通常の製鋼用アーク炣の 炉体に，黑鉛電極の代わりに非消耗のプラズマトーチを 付け，アルゴン・プラズマアークを熱源として金属を溶 解する.このプロセスの最初の工業化は, 米国の Union Carbide Corp.の Linde 研究所で試みられ，その絬果
が報告されたのは 1962 路であつた。 その後，英国の British Oxygen Go. や English Steel Gorp. の開発研 究も行われたが，しかし，いずれも進展せずに終わつて いる. その理由は明らかでないが，当將としては非常に 高価なアルゴンの使用と厓寿命大型トーチの開発が-十分 でなく、スケールアップによる経済的なメリットが望め なかつたためと推定される。

ソ連に抢いては，鋼換算谷星 $20 \mathrm{~kg}$ の浴解装置によ り溶解容器の形状などの検刢が行われ, 艺の絬果は 1971

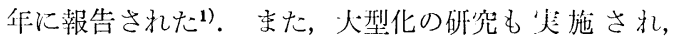

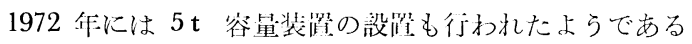
が2)3)，それらの詳細は明確にされていない.

東独に扮いては，1960 作代から PAM プロ七大の開 発研究が開始され，20 kg, $250 \mathrm{~kg}, 3 \mathrm{t}$ 畒星の浴解装置 の開発を経て, VEB/Edelstahlwerk の Freital に 1971 作と 1977 年にとれぞれ，公称行星 $10 \mathrm{t}, 30 \mathrm{t}$ の大型 PAM 炬が各一基設置された。この邽大型炉は, 没置後 に設備・操業の両面から改善が沜えられ, 現在では, 公 称容量をそれぞれ $15 \mathrm{t}, 35 \mathrm{t}$ に増大して, 㩐造用低合金 鋼, ステンレス鋼, 工具鋼などの星産特殊鋼を溶解対像 として三交代制で操業されているようである ${ }^{3)}$. 


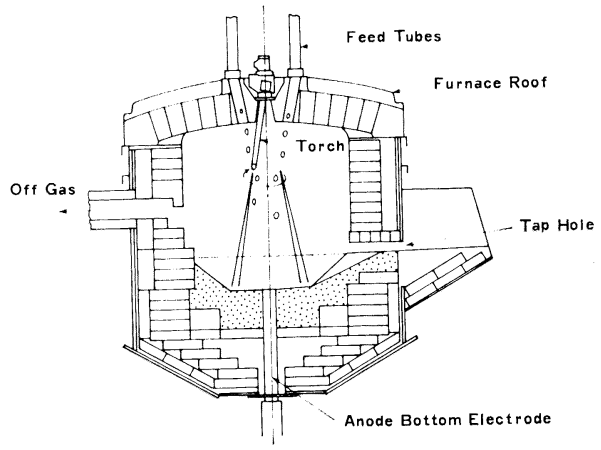

Fig. 2. The plasma arc melting furnace (Foster Wheeler Energy Ltd $^{5)}$ ).

惊独 Freital の公称 $35 \mathrm{t} P \wedge \mathrm{M}$ 炉は，Fig. 1 a) に 示した構造を有し, 側壁に 4 本の移送式直流プラズマト 一チと炉底に銅製の水冷陽極を有している. マグネシア ライニングの耐用吅数は 150 溶解である. プラズマトー チの総出力は $20 \mathrm{MW}$ であり, 常侍 3 本が利用されてい る3). 年間の生痤豊は $80000 \mathrm{t}$ 程度である ${ }^{3)}$.

最近，英国においても，再び PAM 炉の開発に挑戦す る動きがみられる。桨目の Reading にある Foster Wheeler Energy Ltd. は, 获国 Faringdon の Tetronics R \& D Ltd. の開発した移送式值流プラズマトー チを用いて, Fig. 2 に概略の構造を示したPAM 炉の 実用化に取り組んでいる ${ }^{5)}$. 現在の試験炉は， $1.4 \mathrm{MW}$ の直流プラズマトーチ1 本が，灯頂中心に旋回構造で配 備されている。㵋解原料は, トーチ周囲からスクリュー フィーダーで供紷され，プラズマアークの国りにカーテ ン状に落トし，炣の壁や天井のライニングをアークの輻 射損失から保濩する設計である.アークの作動ガスはア ルゴンである. 原料は， $24 \mathrm{~mm}$ 径以下の小片にして供 給される、アークからの浴湯への熱の移行は良好で, ト 一チの冷却熱や炡款への移行熱によるェネルギー損失は 約 $8 \%$ にすぎず，切削油を含むダライ原料の場合，錬 鋼の再生:が，鋼 $\mathrm{t}$ 当たり $500 \mathrm{kWh}$ 程度の電力消費で可 能という。この規模の灿としては非常に良好な䉓力原単 位である. 吏に, $15 \mathrm{MW}$ の出力末でのスケールアップ を現在検詩しているようであるが，果たして，このプロ セスが，10〜30 $\mathrm{t}$ 程度の大型炉まで開発が進行するかど らか興味がもたれる。

また, 最近, 西独において, 移送式交流プラズマトー チ 3 本を炉蓋に有する $3 \mathrm{t}$ 谷量の PAM 炉 (最大電压 $570 \mathrm{~V}$, 最大出力 $1.8 \mathrm{MVA}$ ) が Fried. Krupp GmbH, Krupp Forschunginstitute によつて開発設置され, 更 に, 同時飞 $10 \mathrm{t}$ 谷量の三相交流 PAM 炉 (出力 $9 \mathrm{MV}$ A）の開発計画も進行しているようであるが，それらの 詳細は明らかにされていない。

\section{$2 \cdot 2$ PIM プロセス}

PIM プロセスは，Fig. 1b) に示すように移送式直流 プラズマトーチによる Top heating に誘導加熱攪找を 付加して，効果的なスラグ精鍊をねらつたプロセスであ り，1960 年頃から日本で開発が進められた ${ }^{1)}$. 既に基 礎的研究はほぼ完了し, 1975 年 10 月以降 $400 \mathrm{~kW}$ の プラズマトーチと $600 \mathrm{~kW}$ の誘導加熱攪拌（周 波数 $150 \mathrm{~Hz}$, 正転・逆転攪找可能) 機能を有する容量 $2 \mathrm{t}$ の 炬が稼動中である．2 $\mathrm{t}$ 炉は，現在，高品質を姴求され るステンレス鋼, $\mathrm{Ni}$ 基・ Co 基・ $\mathrm{Fe}$ 基の各種超合 金, $\mathrm{Cu}$ 合金, $\mathrm{Mn}$ 合金，パーマロイなどの電磁材料な ぞの溶解に広範に活用されている。同炉によるステンレ 久鋼 $2000 \mathrm{~kg}$ 浴解時の諸原単位は, 浴解時間 150 $180 \mathrm{~min}$, 精錬時間 60 90 min，電力原単位 $900 \sim 1300$ $\mathrm{kWh} / \mathrm{t}$ ，熱効流約 $30 \sim 45 \%$, アルゴン原単位〜 $10 \mathrm{Nm}^{3} / \mathrm{t}$ 程度である.

ソ連においても，高楇波誘導加熱とプラズマトーチ加 熱とを併用した容器 $30 \mathrm{~kg}$ の装置による基礎研究がなさ れており，1971 年に報告されているが1)，その後の進 展を示す報告はない。

\subsection{PAR プロセス}

プラズマアークを熱源とした水冷だールドを用いた連 続鋳造方式による金属の再溶解プロ七スの研究も，1960 年代から，チェコ，ソ連，日本などで史施された1).

Fig. 1 c ) に, ソ連の Paton 研究所で開発したPA R方式を示したが，ソ連には，この方式の装置として， 交流移送式プラズマトーチ 6 本（総出力 $360 \mathrm{~kW}$ ) を有 する最大モールド径 $250 \mathrm{~mm}$ で最大 $450 \mathrm{~kg}$ の鋼を再溶 解できる装㯰が設置されている. また, 総出力 $500 \mathrm{~kW}$ の直流移送式と総出力 $1800 \mathrm{~kW}$ の交流移送式のP A R 装置が，それぞれ，Paton 研究所によつて設計製作され ているよらである2)6)7). ソ連に扎いては，耐熱鋼，ステ ンレス鋼，窒化鋼の再溶解が対象とされており ${ }^{2)}$, 特に 4 気圧といら高压下での高 $\mathrm{Ni}-\mathrm{Cr}$ 窒化鋼の製造研究が 盛んである8). しかし，操業データの報告はほとんどな されていない。

日本では, 出力 $150 \mathrm{~kW}$ の自流移送式 PAR 装置によ つて軸受鋼，工具鋼， $\mathrm{Ni}$ 基および $\mathrm{Fe}$ 基の超合金を浴 製し，PAR プロセスの特徵を明らかにした ${ }^{9)}$.

その他，米国，西独，ベルギーなどでも PAR プロセ スの開発研究が行われたが299), その後の進展は報告さ れていない.

\section{4 特殊なプラズマアーク溶解精錬鋂造プロセス}

$\mathrm{Ti}$ のように酸素, 窒素, 水素, 炭素との反応性に富 む活性金属は, 酸化物系, カーボン系, 窒化物系いずれ の耐火物とも反応するため, 水冷銅モールドを用いて真 空下でアーク溶解して，熱間加工に供しうる金属チタン インゴットを得るのが通常の製造法である. しかし，こ の方法は，スポンジ原料をブロック状にプレス成型し， 
ブロック同志を溶接組み立てて自溶性電極とする必要が あり，この電極の製造コストが大きく問題点となつてい る.

プラズマアークの特徵を活用して $\mathrm{Ti}$ などの活性金属 を安価浲造するプロセスの開発が日本で進められてい る. Fig. 1d) に, 大同特殊鋼(株)が開発した PPG プ 口セスの概略を示したが，このプロセスは，スポンジ原 料もしくはスクラップ原料を連続的に水冷モールド内に 装入し，プラズマアーク加熱によつて溶解しつつ生成す るメタルプールの上面をモールド内の所定の高さに保持 しながら，モールド内に生成した鋳塊を順次下方に引き 下げ，再溶解用電極もしくは直接熱間加工に供しらるイ ンゴットを製造する方法で㟧る10).

大同特殊鋼は, 更に, Fig. 1 e ) K示したプラズマア 一クを熱源とする傾注可能な水冷モールドを用いるスカ ル炉形式の PSG プロセスを開発し， Ti, Cr, Mn など の金属・合金が溶解できることを示した11) 13).

また，真案下の熱陰極放管を利用した $\mathrm{Ti}$ の溶解プロ セスが，日本ステンレス(株) と日本真空技術(株) との共 同で開発されている ${ }^{14)}$.これは, 中空熱院極放電による プラズマ電子ビームにより溶解を行うものであり，Fig. 1f）に示したごとくGunを多数配置した溢流溶解方式 である1). 現在, 総出力 $2400 \mathrm{~kW}$ (6 gun) の装置によ り，スポンジチタンから直接 $3 \mathrm{t}$ のスラグインゴットが 製造されている，このプロセスは，電力消費が大きいた め, $\mathrm{Ti}$ の溶解に限つて用いられているよらであり, プ ラズマ電子ビームを特殊鋼などの溶解に適用した結果は 発表されていない。

\section{5 製銑分野におけるプラズマアークの利用}

鉄鉱石の還元にプラズマアークを熱源として利用しょ らといら試みは, 1960 年代中頃から行われている。 乙 かし，実際に鉄鉱石から溶鉄を製造するプロセスにプラ ズマアークを熱源として利用した開発研究が，米国の Bethlehem Steel Corp.で実施されたのは 1970 年代に なつてからである. Bethlehem Steel Corp.は, 出力 $100 \mathrm{~kW}$ の試験装置による研究結果を踏まえて, 総出力 $1 \mathrm{MW}$ の直流プラズマアーク加熱装置に，鉱石，天然ガ ス，水素を供給して直接溶鉄を得る開発研究を行つた。 その結果として，プラズマ作動ガスとして $67 \%$ 水素$33 \%$ 天然ガスの混合ガスを用いることにより，低硫黄， 低燐のーマタイト鈗石から， $0.006 \% \mathrm{C}$ の溶鉄を $1 \mathrm{~h}$ 当 たり $320 \mathrm{~kg}$ の速度で製造することができて，その場合 の電力消費量は溶鉄 $1 \mathrm{~kg}$ 当たり $2.65 \mathrm{kWh}$ であり, 熱効率は $84 \%$ 程度であると報告している15). しかし， その後の進展はないようである.

最近, スウェーデンの SKF Steel Engineering AB は, 米国 Westinghouse Electric Corp. の開発した非 移送式プラズマトーチを用いて，従来の製銑プロセスへ のプラズマアーク加熱の利用を陚みている。この製銑プ

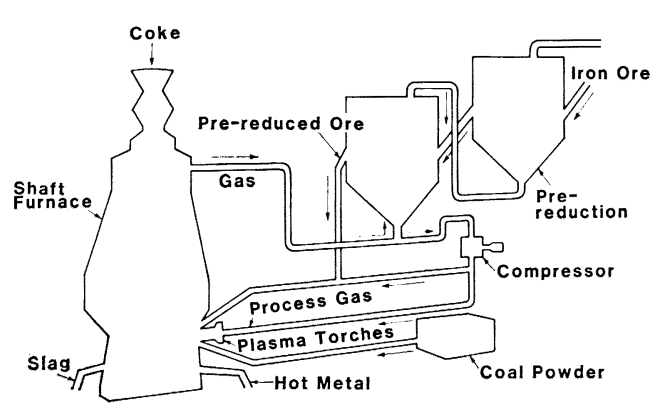

Fig. 3. The scheme of plasmasmelt process (SKF).

ロセ火は, Plasmasmelt process と呼ばれている ${ }^{16) \sim 18) . ~}$ このプロセスは，概略を Fig. 3 に亦すごとく，シャフ ト炉内をコークスで満たし，一予備還元した鈗不精鉱を， 造涬材と主として石炭からなる還元材と共に, シャフト 炉内へ吹き込み還元溶融して溶銑を得るプロせスであ る.

このプロセスに要する熱エネルギーは，プラズートー チ内でアーク加熱された還元ガスによつて供給される. プラズマトーチ内の還元ガス温度は $3000 \sim 5000^{\circ} \mathrm{C}$ で ある. シャフト炉内に吹き込まれた還元ガ入は, 鈗石の 還元溶融に供され吸熱反応により念激に $1700 \sim 2000^{\circ} \mathrm{C}$ に低下する. 更に, シャフト炉をに界して行く過程で上 昇ガス中の $\mathrm{CO}_{2}$ と $\mathrm{H}_{2} \mathrm{O}$ は, シャフト炉内のコークス カーボンで還元される. 主として $\mathrm{CO}$ と $\mathrm{H}_{2}$ とからな

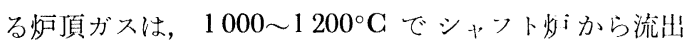
し，鉣不の予備還元に供するために $800^{\circ} \mathrm{C}$ まで冷却さ れる，そのガスの一部が圧縮され，プラズマアーク作動 ガスと造涬材や還元材の搬送吹き込みガ大として利用さ れる，本プロセスに打勈備還元䋇は $50 \sim 60 \%$ と想 定されている.

$\mathrm{SKF}$ の Hofors の $0.4 \mathrm{MW}, 1.5 \mathrm{MW}$ のパイロット プラントによる試験では, 最終工程であるシャフト灯内 の還元試験のみの結果であるが，堂元度 $50 \%$ のスポン ジ状酸化鉄を炉内に供給し，プラズマアーク加熱したガ スにより溶銑が得られることを報告している17).

更に，パイロットソ゚ラントに打る仼験紨果に基つい て Plasmasmelt processによる浴銑製造コス卜の武算を 行い, Table 1 に示すごとく, 年座: $250000 \mathrm{t}$ のプラン トによる溶銑製造が年産 $2000000 \mathrm{t}$ の浴鉱炉プロセス よりも有利であると主張している18).

また, ベルギーの Seraing の Cockerill Steel Corp. に拈いては, 日産 $500 \mathrm{t}$ の溶鉱炉に $3500 \mathrm{~kW}$ のプラズ マトーチをFig. 4 に示ずでく羽山部にとりつけ, 600 $\sim 800 \mathrm{Nm}^{3} / \mathrm{h}$ の天然ガスを過熱して吹き认久溶鉱炉の 生産性向上を試みているようであるが，ての䍩細は明ら かでない18). 
Table 1. The economic comparison between plasmasmelt and blast furnace processes for ironmaking [after ref. 18].

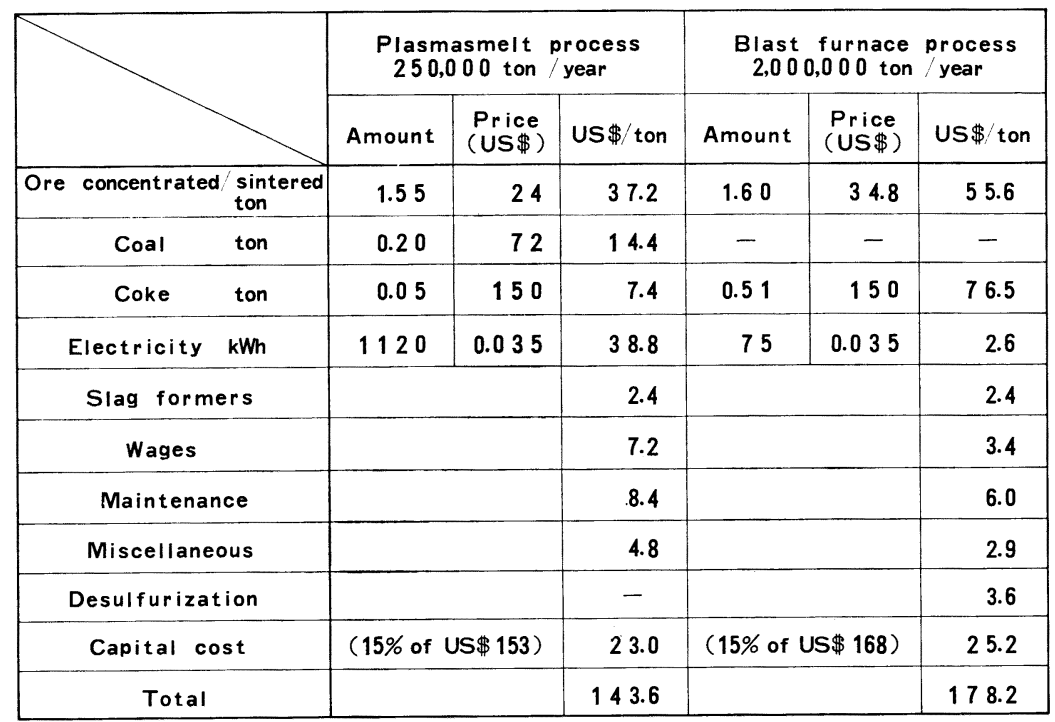

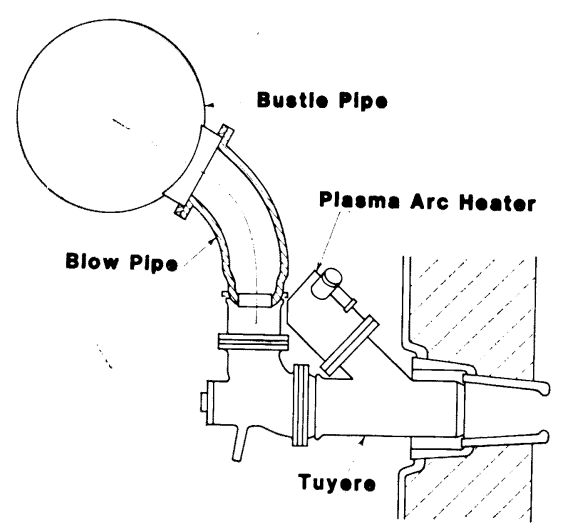

Fig. 4. The modified tuyere for plasma arc heating (Cockerill18) .

\section{3. プラズマアーク溶解プロセスの将来性}

第 2 章に示したごとく, 東欧圈だけでなく, 自由経済 圏でも，プラズマアーク加熱を特殊溶解の分野だけでな く大量生産の象徵ともいらべき溶銑製造の分野にまで利 用しよらとする動问がみられる.

電力価格の高い日本においては考光難い溶銑製造への 適用が試みられている背景をみてみると，プラズマアー クを熱源とする利点として, 環境污染が少なく初期設備 投資が小さいこと，小容量プラントでも操業コストが小 さいこと，既存の溶鉱炉に適用でさることなどを上げて はいるが，その根底には将来の資源・エネルギー問題が 存在している.
第 1 に資源的には，製鉄用コークスの入手が将来困難 になることが上げられている。例えば，米国の場合， 1985 年には約 11 百万 $\mathrm{t}$ もの不足が見达まれている ${ }^{19)}$. Plasmasmelt プロセスによれば, Table 1 に示されてい るように，石炭で供給される炭素分を考虑しても，コー クス比が溶鉱炉プロセスの半分以下になると推定されて いる.

第 2 にェネルギー的には, 石油, 天然ガス, 石炭などの いわゆる化石燃料は枯渴の一途をたどり, それらの価格 は上昇を続けると子想されている，それに対して，プラ ズマアークのエネルギーである電気の価格がぞのように 変化するか子想は非常に難しいが, 原子力, 地熱発電, その他の開発途上技術による発電により，その上昇の度 合は化石系然料に比較して緩やかであるといら考えああ る. 例光ば，米国では，Fig. 5 に示すごとく電気価格 の化石系燃料価格に対する比率は 2 倍程度に将来なると 予想されている18).

確かに，日本においても，Fig. 6 に示すごとく， 1973 年の第 1 次オイルショック以降の原油価格 (CIF) 並びに大口電力料金（電力 9 社の平均料金）は, 1973 年 対比で 1980 年において石油価格が 8 倍になつたのに対 して電力料金は 4 倍と緩やかな傾向を示している20)21).

電気を用いるプラズマアークプロセスは, 確かに, 通 常の燃焼プロセスに比較して，システム制御が容易であ り, 熱エネルギーへの変換効率も優れてはいる. しか し, 将来のエネルギー問題は, 周知のごとく国際情勢や 国のエネルギー政策の変化に伴つて大きく変化する要素 を秘めており，いずれの予想が正鵠を得るかはわからな い. 


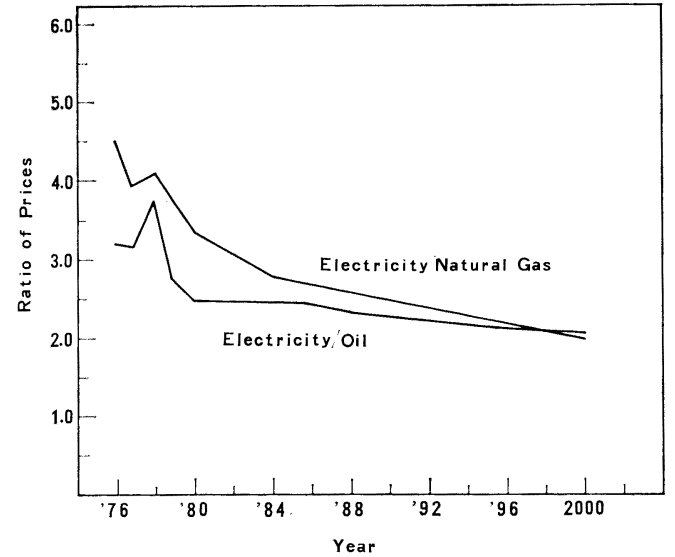

Fig. 5. The trend in energy costs for production (U.S.A.).

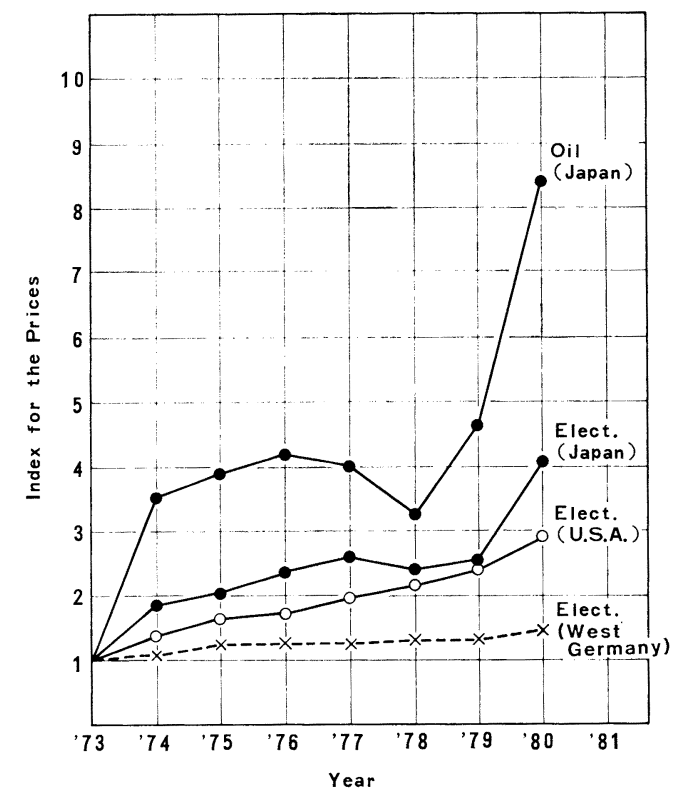

Fig. 6. Cihanges of electricity and oil prices for production.

また, スウェーデンのように, 発笔比摔がオイルショ ック前 1972 年で水力 $75 \%$, 原子力 $2 \%$, 火力 $23 \%$, 1978 年では水力 $62 \%$, 原子力 $26 \%$, 火力 $12 \%$ と化 石系燃料発電の比率が極端に低い国と ${ }^{22)}$ ，日本のように い束だ70\%が火力発電に依存している国とでは，おのず から立場が異なる．化石系然料の価格上昇が急であるか らといつて，プラズマアーク加熱主体の製銑プロセスが 北欧，西欧之同様に有利になるとはいえない，日本の溶 鉙炉製銑にとつては，ベルギーの Cockerill Steel Corp. で実施されている助燃操業の形が一つのヒントであ ろら.
溶銑プロセスにかぎらずプラズマアークを熱源とする 金属の溶解プロセスは，いずれも上述した将米のエネル ギー問題と関連して㧍り，その将米性を経済の観点から 定量的に論ずることは非掌に困難である。

以下に，笑用化されているプラズマアーク浴解プロせ スについて，プラズマアークによらない他の溶解プロ七 スと比較しながら，主として技術面から定性似に将来性 を簡単に述べてみたい。

\subsection{PAM プロセス}

東独の PAM 炉の利点として，通常の製鋼朋アーク炏 に比して，スクラップ中の有価金属の问収歩留りが良好 なこと，プラズマアークが安定であり，更に密閉型の炉 であるため大気污染と騒音とが少なく，特に灼夙辺の騒 音が $80 \mathrm{~dB}$ と小さいこと，非消耗䉓極であるために極低 炭素鋼の溶製に好都命であることが.しげられている ${ }^{3) 4}$. しかし，操業データ並びに経済指標データの公衣が少な く，現在の黒鉛電極の製鋼用アーク炣との比較郭価は非 常に難しい.

Table 2に，東独の $35 \mathrm{t}$ PAM 为とと扎刘心する 谷量の国内アーク炉の操業データの刘比をふ小多.

公表されている東独 $35 \mathrm{t}$ PAM 灯の生産性ならびに 電力原単位は非常に良好であり ${ }^{3)}$ ，泪内の High power クラスのアーク灯のそれらに敵するよらにみえる。 し かし，42CrMo4 (JIS-SCM 440 相当) の浴解例では, 剀 鋼量 $36.3 \mathrm{t}$, 浴け落ちまでの所要侍間 $115 \mathrm{~min}$, 全溶解 時間 $195 \mathrm{~min}$, 電力原単位 $540 \mathrm{kWh} / \mathrm{t}$ ，アルコン原単位

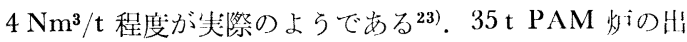
鋼から再送電までの半均所岀時閒が不明であり， Tap to tap 壯間基準の正確な比較ができないが， Table 2 に 示したアーク炉の Tap to tap 壯開は $140 \mathrm{~min}$, H鋼か ら再送電までの平均所装時間 $10 \mathrm{~min}$ 程度であることを 考虑して，送電から証鋼までの全浴解時間基潐で比較す ると生産性は PAM 炉 $11.2 \mathrm{t} / \mathrm{h}$ ，アーク淿 $16.0 \mathrm{t} / \mathrm{h}$ 之 なる．ここに示したアーク炉のデータは，取鍋精錬など の炉外精錬プロ七スと速続操業しないアーク灼门みで構 造用低合金鋼を浴製した埸全の妆地值を小したもので ある。この生産性の比較からみれば，日本におけるP A M炉の設置は，現状では考えにくい。

しかし，日本のアーク炉製鋼の将米を考えた埸合， PAM 炉の非消耗電極の魅力は留意しておく必要があ る. 現在, 日本の $70 \sim 80 \mathrm{t}$ 行星クラスの大型 Ultra high power 炉では, 電力原単位. $400 \mathrm{kWh} / \mathrm{t}$ を切りつ つあり，既に極限に近い状態にある。このような状態 で，黑鉛電極の $4.0 \sim 4.5 \mathrm{~kg} / \mathrm{t}$ 程度の消耗は無視し難 い. Fig. 7 に日本および米国の黑鉛電極のオイルショ ック以降の価格の変化を示したが, 1973 年に比較して 電極価格も電力料金と同様に 3.5 倍と佔上がりしてい る. 現在，アーク炉製鋼コストに上める菓極費は，溶解 電力費の約 $1 / 3$ 程度と大きい. 
Table 2. Contrast between PAM and EF processes.

\begin{tabular}{|l|c|c|}
\hline & P A M & E F \\
\hline Actual melting capacity ton & $35 \sim 36$ & 36 \\
\hline Electric input (Max.) & $20,000 \mathrm{~kW}$ (D.C.) & $19,000 \mathrm{kVA}$ (A.C.) \\
\hline Secondary voltage V & $150 \sim 700$ & $106 \sim 330$ \\
\hline Secondary current (Max.) A & 10,000 torch & 33,200 ( 3 phase) \\
\hline Operating current A & 9,000 torch & 27,700 ( 3 phase) \\
\hline Number of electrodes & $3(4$ equipped) & 15 \\
\hline Productivity $t / h$ & 20 & $480 \sim 500$ \\
\hline Electric power consumption $\mathrm{kWh} / \mathrm{t}$ & (from power on to meltdown) & (from tap to tap) \\
\hline Argon consumption $\mathrm{Nm} / \mathrm{h}$ & 45 & - \\
\hline Graphite electrode consumption $\mathrm{kg} / \mathrm{t}$ & - & 4.5 \\
\hline Torch life $\mathrm{h}$ & (from power on to meltdown) & - \\
\hline
\end{tabular}

[Figures for PAM are after ref. 3 ]

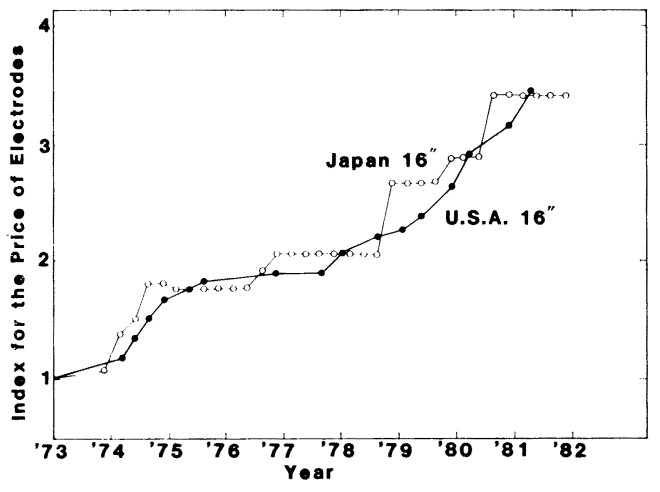

Fig. 7. Drifts of electrode prices in Japan and U.S.A.

一j PAM プロヒスで大熋に使用するアルジンの価格 は，酸素転灼の浽及に伴ら酸素副産アルゴン量の増大す あり，過去: 10 年閣汇とんど変動していない. PAM プ ロセスの銅 $\mathrm{t}$ 当たりのアルジン費は，日本のアルゴン価

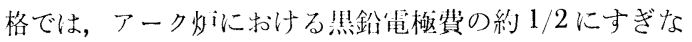
い.

今後のアルゴン㑛格の推移については予断を許さない ものがあるが，日本のステンレス鋼の現在の主要な溶製 技術であるAOD プロセスの稼動状沅からみて，アルゴ ンを大量に使用する溶解法はもはや特殊なプロセスとは いえない時代になりつつある。このような観点に立て ば，技術改善により，PAMプロセスの生産性が電力原
単位，炉用耐火物原単位と共にアーク炉プロセス程度に 向上し，日本の量産特殊鋼製造において一般に行われて いるアーク炉と炉外精鍊との複合操業によつて得られて いる材質が，PAM プロセスのみで得られるようになれ ば，PAM プロセスが有利になる状況も考觉られる.

しかし，なによりも，プラズマトーチの寿命延長が当 面重要である. 現在の東独炉に使用されている大出力ト 一チの寿命は $30 \mathrm{~h}$ と公表されているが，陰極が完全に 溶損することを避け，補修，交換を容易にするためと思 らが，それにしても短寿命である．少なくとも1週間程 度の連続使用に耐えるトーチの開発が，能辫的な操業を 行ら上で必要であろら。

\subsection{PIM プロセス}

PIM プロセスは，真案誘導炉 (VIM) プロセスに対 応する溶解法として開発された. Table 3 に，鋼換算で $2 \mathrm{t}$ 程度の谷量炉を想定した場合の雨プロセスの定性的 比較を示した。

PIM プロセスは，大気圧下の調整雲囲気溶解が特徴 である，従つて，原料の装入が容易であり，測温，サン プリング，造澾材の添加などの作業が簡易で，操業面で 有利である。また，溶湯表面のアーク加熱も本プロセス の特徴で, 誘導加熱攪找とあいまつて，スラグ精鍊が迅 速かつ十分に垁施できる，従つて，溶融金属の脱酸・脱 硫が容易で，低酸素低硫黄の金属が，より安価な原料か ら溶製できる.

これに対して，VIM プロセスは，スラグ精鍊やガス 精錬を行わないのが通例であり，高炭素鋼でも脱硫は余 
Table 3. Merits and demerits of VIM process and PIM process.

\begin{tabular}{|l|c|c|c|}
\hline & V I M & $\begin{array}{l}\text { Judg- } \\
\text { ment }\end{array}$ & P I M \\
\hline Heat source & $\begin{array}{l}\text { High-or commercial frequency } \\
\text { induction }\end{array}$ & & $\begin{array}{l}\text { Combination of plasma arc } \\
\text { and induction }\end{array}$ \\
\hline Operating pressure & $10^{-3} \sim 760 \mathrm{mmHg}$ & $>$ & $760 \mathrm{mmHg}$ \\
\hline Crucible & MgO etc. & $=$ & MgO etc. \\
\hline Raw material & Scraps graded and shaped & $<$ & Various materials \\
\hline Control of chemical comp. & Possible & $<$ & Easy and effective \\
\hline Control of bath temp. & Possible & $<$ & Easy and effective \\
\hline Slag refining & Possible but difficult & $<$ & Easy and ef fective \\
\hline Power consumption & $\sim 0.8-1.5 \mathrm{kWh} / \mathrm{kg}$ & $=$ & $\sim 0.9-1.3 \mathrm{kWh} / \mathrm{kg}$ \\
\hline Surface quality of ingot & Good & $=$ & Good \\
\hline Yield in billeting & Low due to cropping top of ingot & $<$ & High with less cropping \\
\hline Mn recovery & Low due to evaporation loss & $<$ & High up to $98-100 \%$ \\
\hline Al, Ti recovery & Excellent & $>$ & Good \\
\hline Desulphurization & Difficult & $<$ & Ready to reduce S below \\
\hline Capital cost & High & $<$ & Low \\
\hline
\end{tabular}

Table 4. Comparison of variows remelting processes.

\begin{tabular}{|c|c|c|c|c|}
\hline & VAR & E S R & E B R & P A R \\
\hline Heat source & Arc & $\begin{array}{l}\text { Mainly } \\
\text { resistance }\end{array}$ & $\begin{array}{l}\text { Electron } \\
\text { beam }\end{array}$ & Plasma arc \\
\hline Imposed current & D.C. & A.C. (DC) & D.C. & D.C. (A.C.) \\
\hline Power consumption & $1 \mathrm{kWh} / \mathrm{kg}$ & $1.5 \mathrm{kWh} / \mathrm{kg}$ & 1 to $2 \mathrm{kWh} / \mathrm{kg}$ & 1 to $2 \mathrm{kWh} / \mathrm{kg}$ \\
\hline Capital cost & Lower than EBR & Lowest & Highest & Lower than VAR \\
\hline Addition of alloying elements & Impossible & Possible & Impossible & Possible \\
\hline Melting rate control & Difficult & Difficult & Easy & Easy \\
\hline Bath temp. control & Difficult & $\begin{array}{l}\text { Possible but } \\
\text { difficult }\end{array}$ & Easy & Easy \\
\hline Operating pressure & $10^{-2}-10^{-3} \mathrm{mmHg}$ & $760 \sim 10 \mathrm{mmHg}$ & $10^{-4}-10^{-5} \mathrm{mmHg}$ & $760 \sim 10^{-2} \mathrm{mmHg}$ \\
\hline Slag refining & Impossible & Most effective & Impossible & Possible \\
\hline $\begin{array}{l}\text { Melting of high } \mathrm{Mn} \text { or } \mathrm{N} \\
\text { alloys }\end{array}$ & Difficult & Possible & Impossible & Possible \\
\hline $\begin{array}{l}\text { Melting of } \mathrm{Al}, \mathrm{Ti} \text { bearing } \\
\text { alloys }\end{array}$ & Possible & Difficult & Difficult & Possible \\
\hline Yield & Good & Better than VAR & Less than VAR & Better than VAR \\
\hline Ingot surface quality & Not good & Excellent & Good & Good \\
\hline Solidification process & Progressive & Progressive & Progressive & Progressive \\
\hline Reduction of oxygen & Very effective & Effective & Very effective & Effective \\
\hline "nitrogen and hydrogen & Some & None & Some & A little \\
\hline "oxide inclusions & Some & Some & Some & Some \\
\hline "sulphide inclusions & No & Considerable & Considerable & A little \\
\hline
\end{tabular}

り期待できない。交た，通常インゴットの押湯部がより 大きく，押湯部切り捨てによる歩留り減少が大である. しかし，溶融金属を直接減圧下で長時間処理できるの で, 脱水素, 脱窒素の面では有利である.

PIM プロセスの今後を考えると，プラズマアークの 熱効率向上, アルゴン使用量の低減などの改善努力は今 後共続ける必要はあるが，スラグ精錬とガス精錬が容易 で安価なスクラップを多量に利用できる, 高級金属材料 の有利な製造プロセスとして活用されることが期待され
る。また，VIM+VAR (真空アーク再溶解) のごとき 複合プロセスに拈いては，VIM プロセ入にとつて代わ ることができると考えられる.

しかし，特殊鋼溶解における炬外精錬技術とりわけ交 流アーク加熱・ガス攪拌方式の取鍋精錬技術の著しい発 展に伴い, 量産特殊鋼生産分野における PIM プロヒス の必要性は少なくなつている. 従つて, PIM プロセス の規模は，高級高品質材料を溶製するに適当な数 $\mathrm{t}$ 容量 に留まると予想される。 


\section{3 .3 PAR プロセス}

超合金や高級高品質鋼の再溶解に用いられている P A $\mathrm{R}$ プロセ入は, 従来からある真空アーク再溶解( V A R)， エレクトロスラグ再溶解 ( $\mathrm{ESR}$ ) に対伈するプロセスで ある。また，東独で盛んに大型化が武みられているェレ クトロンビーム再溶解 $(\mathrm{EBR})$ プロセス1)にも対応する と考觉られる。

VAR，ESR は，门浴性杗極に上る加熱才式であるの に対して, PAR と EBRは, 非消耗のトーチもしくは 電子銃による加熟う式である.

これらのブロ七大の䇥性们な比較を, 各再浴解プロセ スに拈いて其通の設借諸元の1つと考光られる水冷モー ルド径が $300 \mathrm{~mm}$ 程度の装置を想定して Table 4 に示 した. PAR は高压雲明父ドの再浴解が可能な装置も㐫

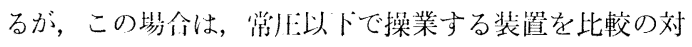
象とした。

PAR プロセスは，第 1 に，ガス雲囲気下もしくは減 压トでの操業が叫能である. 従つて, 溶解雾囲気の組成 と珐才とを調整することにより，VAR， ESR，EBR の 各プロ七久では変動しやすい $\mathrm{Mn}, \mathrm{Cu}, \mathrm{N}, \mathrm{Al}, \mathrm{Ti}$ な どの元素を多く含を金属材料の再溶解に適している，第 2 に, プラズーアーク出力と再溶解速度とをそれぞれ独 立に制御できるため，インゴットの凝固コントロールを 幅広く行らことができる. 従つて, 偏析のない熱間加工 の艮好なしかも皮削是や頭部切り唅て量の少ないインゴ ットが得られる。符 3 に, 設備費が EBR, VAR プロせ スより少なくてすみ大型化が容易である.

それ故に, VAR E ESR プロセスよりも凝固組織の 優れた大型インゴットが安価に得られる. 将来, 難熱間 加工材の量産化に適したブロセスとしての発展が期待で きる.

\section{4 その他のプロセス}

プラズーアークは, 既述のように各種の形式の溶解精 錬装狊に広く適用できる. 従つて, 溶解対象である金属 材料の原料形態, 物理化学的性質, 要求される成品の形 態と品質特性などに忍じて，浴解精錬装置の形式を適切 に選定すれば，從米の浴解技術では製造が困難であるた わ，工業的に利用されないでいる特殊な性質を有する金 属材料の浴製プロセスが開発される可能性がある。その 例として，2.4 節で触れた PSG プロ七スによる $\mathrm{Cr}$, Mnなどの浴解がある.

また，プラズマアークにより，スポンジ状，塊状，千 ップ状の原料の浴解が可能であり， $\mathrm{Ti} ， \mathrm{Ti}$ 合金と同様 に, 現在, スクラップの再生が問題になりつつある $\mathrm{Zr}$, $\mathrm{Nb}$ などの特殊な金属材料の溶解への適用が，将米大い に期待される.

ももろん，溶融全属の温度制御のための熱源としての 利用，例えば，取鍋や連綎鋳造用タンデッシュにおける

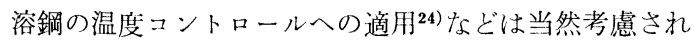

よう.

更に, プラズマアークは，金属のみならずセメントや 耐火物などの溶解にも利用できるので，特殊な利用と乙 て, 䀯電性のないセメントなどの灭雑物を含有する産業 廃棄物の溶解減容積処理にも適用されよう25).

このよらに，プラズマアークは，単に金属にかぎらず 公範四の物質を Closed system で溶解処理する制御し や哆いプロセスとして幅広く利用できる可能性がある.

\section{4. プラズマアーク溶解プロセスの問題点}

上述のごとく金属の溶解精鍊へのプラズマアークの適 用は，多くの特徵あるプロ七スあるいは金属材料を生み 出寸可能性を有し，その将来が期待される。 しかし，そ れらを現実とするためには，解決を要する問題点もまた 多い.その主な点について以下に簡単に述べる.

第 1 の問題点として大出力で寿命の長いプラズマトー チの開発がある.プラズマトーチは, アークの発生方式 から移送式と非移送式に大別されているが，金属の溶解 には，熱効率の観点から溶解する金属を対極とする移送 式トーチが用いられる場合が多い1).

現在日本でも，アルゴン拘束直流移送式プラズマトー チとして出力 $1 \mathrm{MW}$ 程度の長寿命大型トーチが既に開 発されている26). また，米国の Westinghouse Corp.に おいては，ガス加熱のための非移送式の $3 \mathrm{MW}$ 程度の 直流もしくは交流の管状プラズマトーチが開発されてい る16)18). しかし，3.1 節でも触れたように，大型 PAM 炏の安定操業には，1週間程度の連続使用に耐える 5 MW以上の超大出力トーチの開発が必要である.これ は, 今後のプラズマアーク溶解の発展のために解決すべ き最も難しい問題である.

第 2 の問題として, プラズマアークの高温を効果的に 被加熱体に伝達し溶解精鍊を行らために, 溶解装置の設 計とトーチ操作技術を含めた溶解精鍊操業技術の最適化 の問題がある. 移送式直流プラズマトーチは, アークの 安定が良いためトーチ内に陰極を有する正極性方式が通 常採用されており，その場合のアーク特性として最高温 部はトーチ側にある。 また，プラズマアークの熱効摔 は, トーチの構造, 作動ガスの種類や量, アークの長 さ, 被加熱物の種類や形状, トーチの配置と溶解装置の 構造とによつて大きく左右される ${ }^{1)}$. 従つて効率的な溶 解を行らには, 装置の構造設計と溶解時のトーチ操作に よるアークの形状コントロールに留意する必要がある. これらに関する基礎研究並びに試験装置における経験の 蓄積は今後の課題であろう.

\section{5. 結}

言

以上, プラズマアーク浴解の現状と将来性について概 略の展望を述べた. プラズマアーク溶解は, 現在, 高品 質鋼，超合金，電磁材料，特殊金属合金材料などの生産 
に現寒利用されている。しかし，その工業的応用は，世 界的にみてもまだ緒についたばかりであり，今後ますま す開発研究を進める必要がある，熱源としてのプラズマ アークの利用分野は, 単に金属材料の溶解のみならず各 栝の七ラミックスの合成と溶解，あるいはそれらの超微 粉末の製造など限りなく広い。これらの製造技術の発展 のためにも各種のプラズマアーク発生装置の開発と改善 とが切に望まれる。

本稿の執筆に当たり，大同特殊鋼 (株)高蔵製作所稲垣 悦郎，平竹進の两氏ならびに同中央研究所杉浦三郎，山 田博之の両氏に協力を得た。ここに感謝の意を表するも のである。

\section{交献}

1) 梋山太郎，小野清雄：䜪と鋼，63（1977）13, p. 2010

2 ) N. N. Rikalin: Proceedings of 9th International Congress of UIE, VB 3 , Oct. (1980), Cannes

3 ) $G$. Scharf, $K$. Skuin, $W$. Schlager, and $W$. Lugscheider: Proceedings of 9th International Congress of UIE, II B4, Oct. (1980), Cannes

4) $G$. Scharf and $H$. Jahn : Neue Hütte, 25 (1980) 12 , S 479

$5) J . R$. Monk: Proceedings of 5th International Symposium on Plasma Chemistry, Aug. (1981), Edinburgh, Scotland, 1, p. 162

6 ) E. O. PAton: Welding Institute, USSR, Academy of Science: Plasma arc remelting (in USSR), (1976)

7) Licensintorg Moskva-SSSR: Plasma-Arc Remelting of Metals \& Alloys in Water-Cooled Copper Crystallizer, (1973)

8 ) $G . F$. Yorkhov, $Y u . V$. Latash, $R . R$. Fessler, $A . H$. Clater, $E$. E. Fletcher, and $A$. L. Hoffmanner: J. of Metals, Dec. (1978), p. 20

9 ) 藤原達雄, 加藤洞志, 小野清雄, 山田愽㓅：鉄と 罁, 63 (1977), p. 2224
10) $T$. Fujinara, $K$. Kato, $K$. Ono, and $H$. YAMADA: Proceedings of 6th International Vacuum Metallurgy Conference on Special Melting \& Metallurgical Coatings, $\Lambda$ pr. $23 \sim 27$, (1979), San Diego, California, p. 473

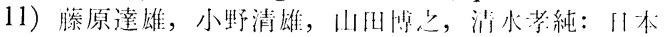
金㥥学全一般溝演概装集， $\Lambda$ pr. (1981) 481， p. 270

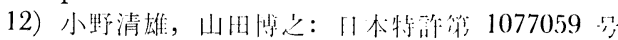
(1981)，12，25

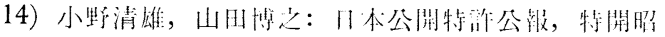
55-21510 C22G (1980)，2，15

14) $Y$. Kotani, $K$. Murase, $F$. Shimizu, $T$. Suzuki, and T. Yamamoto: Extended Abstracts of 4th International Conference on Titanium, May 19 22, (1980), Kyoto, Section X-A, No. 4

15) R. G. Gold, W. R. Sandati, $P$. G. Chepli$\mathrm{CK}$, and $D . R$. MACRAE: Ironmaking and Steelmaking, (1977) 1, p. 10

16) Industrial Heating, Oct. (1980), p. 29

17) Metals and Materials, Mar. (1981), p. 27

18) $M . G$. Fey, $W . J$. Melill, and T.M.Meyer: Preprint for the 5th International Industrial Seminar on Pilot Plant Experience-Melting and Processing Technology, Sept. (1981), Amelia Island, Florida

19) W. T. Hogan: "Analysis of the U. S. Metallurgical Coke Industry" Industrial Economies Research Institute, Fordham University. Oct. (1979)

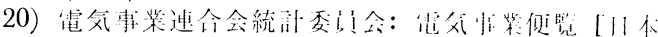
電気協会]

21）日本入油速盟：石油資料月埥

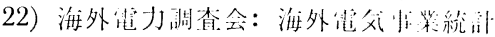

23) 私信

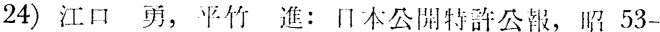
83932， B 22 D (1978) 7，24

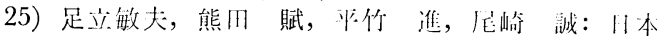
公開特湖公報，昭 56-64699，Ｇ21 F (1981) 6, 1

26) C. Asada, I. Egughi, and T. Adachi: Proceedings of 7 th International Electro-Heat Congress, Warschau (1972), N. 123 